\title{
REGULASI EMOSI PADA REMAJA LAKI-LAKI DAN PEREMPUAN
}

\author{
Hanum Hasmarlin, Hirmaningsih \\ Universitas Islam Negeri Sultan Syarif Kasim Riau, Indonesia \\ hanumhasmarlin@gmail.com,nig153@yahoo.co.id
}

\begin{abstract}
There is a difference in emotional regulation between men and women both biologically and psychologically that poses a difference in the way of thinking, feeling and behavior between men and women. As a result, gender stereotype emerges. This paper discusses the differences in emotional regulation between male and female students in high schools. This is quantitative research with comparative methods. The population is 4262 students who are spread in several public high schools and private high schools in Pekanbaru. The number of sample is 398 students. Samples were taken using the quota sampling technique. The instrument for collecting data is an emotional regulatory scale that has been developed by Gratz and Roemer. The results showed there was a difference in emotional regulation between male students and female students of significance $p=0.000$ and the mean value in males $(M=44.430)$ was higher than that of women $(M=41.88)$. These differences are influenced by differences in suppression expressive and social cultural demands to them.
\end{abstract}

Keywords: Emotional Regulation; Female Student; Male Student; High School

\begin{abstract}
ABSTRAK
Terdapat perbedaan pengelolaan emosi antara laki-laki dan perempuan baik secara biologis maupun psikologis, yang menimbulkan perbedaan dalam cara berpikir, berperasaan dan berperilaku antara laki-laki dan perempuan. Akibatnya, muncul streotype gender, perempuan lebih emosi, pria tidak. Tulisan ini mendiskusikan tentang perbedaan pengelolaan emosi antara siswa laki-laki dan siswa perempuan di Sekolah Menengah Atas Pekanbaru. Penelitian ini adalah penelitian kuantitatif dengan metode perbandingan. Jumlah populasi adalah 4262 siswa yang tersebar di beberapa Sekolah Menengah Atas Negeri dan Sekolah Menengah Atas swasta di Pekanbaru. Jumlah sampel adalah 398 siswa. Sampel diambil menggunakan tehnik quota sampling. Alat pengumpul data adalah skala regulasi emosi yang telah dikembangkan oleh Gratz dan Roemer. Hasil penelitian menunjukkan adanya perbedaan regulasi emosi antara siswa laki-laki dan siswa perempuan dengan taraf signifikansi $\mathrm{p}=0.000$ dan nilai mean pada laki-laki $(\mathrm{m}=44,430)$ lebih tinggi dari perempuan $(\mathrm{M}=41.88)$. Perbedaan ini dipengaruhi oleh perbedaan dalam expressive suppression dan tuntutan sosial budaya kepada mereka.
\end{abstract}

Kata Kunci: Regulasi Emosi; Perubahan Emosi; Gender

\section{PENDAHULUAN}

Masa remaja merupakan salah satu periode dalam perkembangan manusia yang menarik perhatian untuk dibicarakan. Pada masa remaja, individu banyak mengalami berbagai perubahan meliputi perubahan fisiologis maupun psikologis. 
Salah satu perubahan psikologis yang terjadi pada masa remaja adalah perubahan sosioemosional, dimana remaja memiliki ketegangan emosi yang cukup tinggi. Hal ini dijelaskan oleh Hall (dalam Berk, 2012) bahwa remaja umumnya mengalami konflik yang kompleks, sehingga masa remaja sering dikenal dengan masa "storm and stress".

Berk (2012) menjelaskan bahwa pada masa remaja, individu akan mulai memiliki ketertarikan pada lawan jenis, minat karir dan eksplorasi identitas. Menurut Neff dan McGehee (2010) hal tersebut menimbulkan tekanan tersendiri bagi remaja, seperti tekanan yang dirasakan atas kinerja akademis, kebutuhan untuk menjadi populer, keinginan untuk diterima, merasa cocok dalam suatu kelompok sosial yang tepat, permasalahan hubungan dengan lawan jenis dan body image. Keadaan yang demikian, ditambah dengan perubahan emosional yang dirasakan remaja, perubahan minat, peran dan kondisi lingkungan yang menimbulkan tekanan sosial, membuat ketegangan emosi pada remaja semakin bertambah tinggi.

Permasalahan dan tekanan yang ada di dalam kehidupan sehari-hari pada hakikatnya merupakan suatu batu loncatan untuk membuat remaja menjadi lebih dewasa dalam bertindak. Untuk dapat menghadapi situasi yang menekan dengan menampilkan perilaku yang adaptif maka remaja membutuhkan regulasi emosi. Hurlock (2011) menjelaskan remaja memiliki pengelolaan emosi yang baik jika mampu menilai situasi secara kritis terlebih dahulu sebelum bereaksi secara emosional. Sedangkan ketidakmampuan mengelola emosi dapat membuat remaja tidak berdaya menghadapi situasi penuh tekanan dan konflik, akibatnya remaja melakukan tindakan destruktif untuk mengelola emosi yang sedang dihadapinya.

Piaget menjelaskan bahwa perkembangan kecerdasan kognitif pada masa remaja telah sampai ke tahap maksimal (dalam Desmita, 2012). Remaja telah mampu berpikir secara sistematik dan memikirkan semua kemungkinan untuk memecahkan permasalahan. Meskipun kemampuan kognitif remaja sudah berkembang, tetap saja masih ada ketidakmatangan kognitif yang menyelimuti, misalnya imaginary audience dan personal fable (Elkind dalam Berk, 2012). Bentuk-bentuk ketidakmatangan dari remaja ini mendasari banyaknya perilaku beresiko dan destruktif yang dilakukan remaja, dan memberikan kontribusi peningkatan self-criticism, perasaan terisolasi, dan overidentification dengan emosi yang dirasakan.

Berbagai fenomena yang dapat dijadikan contoh berkaitan dengan ketidakmampuan remaja dalam mengelola emosi adalah peristiwa bunuh diri yang dilakukan oleh remaja berusia 17 tahun yang berstatus pelajar di Indragiri Hulu. Aksi 
tersebut dilakukan tanpa diketahui penyebabnya (Prahara, 2018). Aksi serupa juga dilakukan oleh siswi SMA berusia 16 tahun di Kampar. Penyebab aksi bunuh diri diduga depresi karena tidak tahan menjadi bahan bully oleh teman-temannya (Kurniawansyah, 2017).

Fenomena kurangnya pengelolaan emosi juga terjadi di Pekanbaru, seperti cekcok hingga nyaris tawuran yang dilakukan oleh dua siswa dari SMAN 15 dan SMAN 12 Pekanbaru. Peristiwa bermula dari siswa SMAN 15 yang menumpang belajar ke SMAN 12 disebakan gedung sekolah SMAN 15 belum selesai. Siswa yang menumpang dihina dengan kata-kata yang tidak pantas (Sani, 2014). Ada aksi perampokan dan penganiayaan yang dilakukan oleh 3 orang pelajar SMA di Pekanbaru. Akibat aksi perampokan dan penganiayaan tersebut, siswa-siswa tersebut tidak dapat mengikuti pelajaran di sekolah (Tanjung, 2014). Selanjutnya, aksi pengeroyokan anggota TNI yang dilakukan oleh siswa SMAN Olahraga Riau saat pertandingan liga futsal di Gelanggang Remaja Pekanbaru. Peristiwa bermula saat salah seorang siswa SMAN Olahraga melempar botol ke lapangan karena tidak puas dengan hasil pertandingan (Azri, 2013).

Kelima kasus di atas dapat dikategorikan bahwa remaja tersebut memiliki pengelolaan emosi yang rendah. Ini sesuai dengan pendapat Hessler dan Katz (2010) yang menyatakan, ketidakmampuan mengelola emosi dapat membuat remaja melakukan tindakan destruktif untuk mengatasi emosi negatif. Cekcok, penganiayaan dan pengeroyakan dapat dikategorikan melakukan tindakan destruktif pada orang lain, sedangkan bunuh diri merupakan tindakan destruktif pada diri sendiri. Penelitian yang dilakukan Ubaidillah (2014) menemukan emosi yang dialami remaja dapat mempengaruhi pengambilan keputusan pada remaja. Kemampuan pengelolaan emosi yang rendah membuat remaja tidak berpikir panjang akan konsekuensi dari sebuah keputusan, sehingga remaja mengambil keputusan yang tidak tepat.

Regulasi emosi mencakup upaya untuk menerima emosi, kemampuan untuk mengendalikan perilaku impulsif dan kemampuan untuk menggunakan strategi regulasi emosi sesuai situasi secara fleksibel (Gratz dan Roemer, 2004). Regulasi emosi yang adaptif melibatkan modulasi pengalaman emosi daripada menghilangkan emosi tertentu. Modulasi rangsangan ini dianggap mengurangi urgensi yang terkait dengan emosi sehingga individu mampu mengendalikan tingkah lakunya. Jika dikaitkan dengan kasus-kasus di atas, maka dapat dipahami bahwa remaja yang melakukan cekcok, penganiayaan, pengeroyokan hingga bunuh diri mengindikasikan 
ketidakmampuan remaja dalam mengendalikan emosi sehingga menampilkan perilaku yang tidak adaptif.

Gratz dan Roemer (2004) menjelaskan bahwa ada empat aspek yang digunakan untuk menentukan kemampuan regulasi emosi individu yaitu: (a) Acceptance of emotional response (penerimaan emosi), yaitu kemampuan individu untuk menerima suatu peristiwa yang menimbulkan emosi negatif dan tidak malu merasakan emosi tersebut ketika menghadapi permasalahan; (b)Strategies to emotion regulation (strategi regulasi emosi), yaitu keyakinan individu untuk dapat mengatasi suatu masalah, memiliki kemampuan untuk menemukan suatu cara yang dapat mengurangi emosi negatif dan individu dapat dengan cepat menenangkan diri kembali setelah merasakan emosi yang berlebihan; (c) Engaging in goal directed behavior (keterlibatan perilaku bertujuan), yaitu kemampuan individu untuk tidak terpengaruh oleh emosi negatif yang dirasakannya sehingga individu dapat tetap berkonsentrasi, berpikir dan melakukan sesuatu dengan baik; (d) Control emotional responses (kontrol respon emosi), yaitu kemampuan individu untuk dapat mengontrol emosi yang dirasakannya dan respon emosi yang ditampilkan (respon fisiologis, tingkah laku dan nada suara), sehingga individu tidak akan merasakan emosi yang berlebihan dan menunjukkan respon emosi yang tepat.

Secara biologis dan psikologis terdapat perbedaan antara pengelolaan emosi remaja laki-laki dan perempuan. Dengan adanya perbedaan tersebut, maka akan terjadi perbedaan dalam cara berfikir, berperasaan dan berperilaku. Hasil penelitian Romer, Ravitch, Tom, Merrell, dan Wesley (2011) menemukan adanya perbedaan fungsi sosio-emosional pada remaja laki-laki dan remaja perempuan. Remaja perempuan memiliki kemampuan sosio-emosional yang lebih tinggi daripada remaja laki-laki, khususnya pada regulasi diri dan kompetensi sosial. Hal ini tidak terlepas dari adanya peran pola asuh orangtua, yang sering kali memperlakukan anak laki-laki dan perempuan dengan cara yang berbeda. Sebagaimana yang disampaikan dalam penelitian Ratnasari dan Suleeman (2017) ada indikasi bahwa emosi dan regulasi emosi merupakan kecenderungan yang dibentuk oleh pola asuh, sosialisasi, dan pendidikan.

Penelitian menemukan bahwa laki-laki dan perempuan berbeda dalam mengekspresikan emosi baik verbal maupun non verbal sesuai dengan jenis kelaminnya (Simon \& Nath, 2004). Perbedaan jenis kelamin dalam pengekspresian emosi dihubungkan dengan perbedaan dalam tujuan laki-laki dan perempuan 
mengontrol emosinya. Perempuan lebih mengekspresikan emosi untuk menjaga hubungan interpersonal serta membuat perempuan tampak lemah dan tidak berdaya. Sedangkan laki-laki lebih mengekspresikan marah dan bangga untuk mempertahankan dan menunjukkan dominasi. Sehingga, dapat disimpulkan bahwa perempuan lebih dapat melakukan regulasi terhadap emosi marah, penghinaan dan jiijk, sedangkan laki-laki pada emosi takut, sedih dan cemas (Matsumoto, Takeuchi, Andayani, Kouznetsova \& Krupp, 1998).

Kemampuan untuk dapat mengelola emosi bagi remaja berhubungan dengan kebiasaan mengalami berbagai masalah yang menekan dirinya seperti kecemasan dan depresi. Bila individu mampu mengelola emosi negatifnya (kesedihan, ketakutan dan kemarahan), remaja tersebut memiliki daya tahan untuk tidak terkena kecemasan dan depresi (Gross, Richards \& John, 2006; Santrock, 2007). Hal ini diperkuat oleh hasil penelitian yang dilakukan oleh Betts, Gullone dan Allen (2009) yang menemukan kemampuan mengelola emosi yang baik merupakan salah satu faktor yang dapat mengurangi risiko depresi pada remaja. Hasil penelitian juga menemukan bahwa perempuan cenderung mengalami depresi dibandingkan laki-laki (Davis \& Katzman, 1997; Gladstone \& Koenig, 2002; Sigmon, dkk., 2006).

Berdasarkan uraian di atas, penelitian ini memiliki tujuan untuk mengetahui secara empiris perbedaan regulasi emosi pada remaja laki-laki dan perempuan. Sedangkan, hipotesis yang dikemukakan adalah ada perbedaan regulasi emosi pada remaja laki-laki dan perempuan.

\section{METODE}

Populasi pada penelitian ini adalah siswa SMAN 3 Pekanbaru, SMAN 11 Pekanbaru, SMAN 12 Pekanbaru, SMAS Tri Bakti Pekanbaru, SMAS YLPI Pekanbaru, dan SMAS Muhammadiyah 1 Pekanbaru yang berjumlah 4262 orang. Sampel yang digunakan sebanyak 398 subjek. Teknik pengambilan sampel yang digunakan dalam penelitian ini adalah nonprobability sampling dengan menggunakan kuota sampling. Kuota sampling adalah teknik untuk menentukan sampel dari populasi yang mempunyai ciri-ciri tertentu sampai jumlah (kuota) yang diinginkan (Sugiyono, 2016).

Pengumpulan data dalam penelitian ini menggunakan skala regulasi emosi berdasarkan aspek yang dikemukakan oleh Gratz dan Roemer (2004). Skala disusun dalam bentuk skala Likert dengan empat alternatif jawaban yaitu Sangat Sesuai (SS), Sesuai (S), Tidak Sesuai (TS), dan Sangat Tidak Sesuai (STS). Berdasarkan analisis 
terhadap 45 aitem skala regulasi emosi yang telah diujicobakan, terdapat 28 aitem yang gugur dan 17 aitem yang valid. Perhitungan uji reliabilitas menggunakan alpha cronbach diperoleh nilai untuk skala regulasi emosi sebesar 0,825 . Teknik analisis data yang digunakan adalah independent $t$ sample test. Penghitungan analisis dibantu dengan menggunakan SPSS (Statistics for Products and Services Solution) versi 22 for windows.

\section{HASIL DAN PEMBAHASAN}

Berdasarkan hasil penelitian diperoleh bahwa remaja yang berusia 16 tahun berjumlah 146 orang (36,8\%), usia 17 tahun berjumlah 208 orang (52,1\%), dan usia 18 tahun berjumlah 44 orang (11,1\%). Sehingga dapat diketahui bahwa sebagian besar subjek berusia 17 tahun. Berdasarkan kategori jenis kelamin diperoleh remaja laki-laki berjumlah 138 orang (52,1\%), dan perempuan berjumlah 260 orang $(65,2 \%)$.

\section{Hasil Uji Hipotesis}

Berdasarkan hasil independent sample t-test dengan menggunakan SPSS 22.0 for windows, maka diperoleh nilai homogenitas sebesar 0,982 dengan signifikansi sebesar $0,000(\mathrm{p}<0,05)$.

Berdasarkan hasil penelitian diketahui adanya perbedaan regulasi emosi antara remaja laki-laki dan perempuan dengan taraf signifikansi $\mathrm{p}=0.000$ dan nilai mean pada laki-laki $(\mathrm{M}=44.43)$ lebih tinggi daripada perempuan $(\mathrm{M}=41.88)$. Hal ini menunjukkan bahwa regulasi emosi laki-laki lebih baik dibandingkan perempuan. Sebagaimana penelitian oleh Gross dan John (2003) bahwa terdapat perbedaan jenis kelamin dalam meregulasi emosi.

Perbedaan ini dapat dipengaruhi oleh sosialisasi yang merupakan salah satu faktor yang berperan dalam menghasilkan perbedaan emosi antara perempuan dan laki-laki. Sebagaimana dalam penelitian Ratnasari dan Suleeman (2017) bahwa perbedaan dalam regulasi emosi secara umum antara perempuan dan laki-laki merupakan konsekuensi dari perbedaan dalam expressive suppression. Perempuan lebih diberi keleluasaan dalam mengungkapkan emosinya. Sedangkan laki-laki dituntut untuk lebih memendam emosinya. Secara umum di Indonesia, perempuan yang larut dalam pengalaman emosi dan cenderung mengekspresikan emosinya lebih diterima dibandingkan dengan laki-laki.

Hasil penelitian yang dilakukan Simon dan Nath (2004) menemukan bahwa laki-laki dan perempuan berbeda dalam mengekspresikan emosi baik verbal maupun non verbal sesuai dengan jenis kelaminnya. Perbedaan jenis kelamin dalam pengekspresian emosi dihubungkan dengan perbedaan dalam tujuan laki-laki dan 
perempuan mengontrol emosinya. Perempuan lebih mengekspresikan emosi untuk menjaga hubungan interpersonal serta membuat perempuan tampak lemah dan tidak berdaya. Sedangkan laki-laki lebih mengekspresikan marah dan bangga untuk mempertahankan dan menunjukkan dominasi. Sehingga, dapat disimpulkan bahwa perempuan lebih dapat melakukan regulasi terhadap emosi marah, penghinaan dan jiijk, sedangkan laki-laki pada emosi takut, sedih dan cemas (Matsumoto, Takeuchi, Andayani, Kouznetsova \& Krupp, 1998).

Brody dan Hall (dalam Lewis, Jones, \& Barret, 2008) menjelaskan bahwa lakilaki lebih menggunakan strategi pengaturan emosi pemecahan masalah, perilaku, dan eksternalisasi lebih dari yang dilakukan perempuan, seperti mengambil langkah aktif, dan terlibat dalam kegiatan fisik seperti olahraga. Sedangkan perempuan menggunakan lebih banyak strategi dukungan sosial; internalisasi strategi, seperti menyalahkan diri sendiri dan strategi yang berfokus pada emosi, seperti merenung, terdiri dari perhatian yang terfokus secara pasif pada pengaruh negatif daripada mengambil langkah aktif. Sehingga hal ini membuat remaja perempuan akan memikirkan secara terus menerus kejadian yang memunculkan emosi negatif (ruminasi).

Gratz dan Roemer (2004) menjelaskan salah satu aspek regulasi emosi yaitu engaging in goal directed behavior yang merupakan kemampuan individu untuk tidak terpengaruh oleh emosi negatif yang dirasakannya sehingga tetap dapat berkonsentrasi, berpikir dan melakukan sesuatu dengan baik. Dapat disimpulkan, jika remaja perempuan terlalu fokus dengan kejadian negatif yang dialami maka ia menjadi berlarut-larut dalam emosi yang dirasakan dan tidak dapat melakukan sesuatu dengan baik sehingga menampilkan pengelolaan emosi yang buruk daripada laki-laki.

\section{SIMPULAN}

Berdasarkan pemaparan hasil penelitian dan pembahasan, dapat ditarik kesimpulan bahwa terdapat perbedaan tingkat regulasi emosi antara remaja perempuan dan laki-laki. Regulasi emosi remaja laki-laki lebih tinggi dibandingkan remaja perempuan. Perbedaan ini dipengaruhi oleh perbedaan dalam expressive suppression dan tuntutan sosial budaya kepada mereka. 
Azri, Anggota TNI Dikeroyok Siswa SMAN Olahraga Riau. Riau Pos [on-line], 2013, Diakses 20 September 2018 dari http://riaupos.co/35071-arsip-anggota-tnidikeroyok-siswa-sman-olahraga-riau.html\#.W-2KNfkzbIU

Berk, L. E., Development Through The Lifespan: Dari Prenatal Sampai Remaja (Transisi Menjelang Dewasa), Yogyakarta: Pustaka Pelajar, 2012

Davis, C. dan Katzman, M, Charting new Territory: Body Esteem, Weight Satisfaction, Depression, and Self-esteem Among Chinese Males and Females in Hongkong, A Journal Research, Vol. 36; Issue: 7, 1997

Gladstone, T.R.G. dan Koenig, L.J., Sex Differences in Depression across the High School to College Transition, Journal of Youth and Adolescence, Vol.23: Issue; 6, 2002

Gratz, K. L., dan Roemer, L., Multidimensional Assessment of Emotion Regulation and Dysregulation: Development, Factor Structure, and Initial Validation of the Difficultiesin Emotion Regulation Scale, Journal of Psychopathology and Behavioral Assessment, 26, 2004

Gross, J., Richards. M., dan John, O. P., Emotion Regulation in Everyday Life, 2006. $\begin{array}{llll}\text { Diakses } & 2 & \text { Februari } & 2018 \\ \end{array}$ http://media.rickhanson.net/Papers/EmotRegDaily\%20Life.pdf

Hessler, D.M. dan Katz, L.F., Brief report: Associations Between Emotional Competence and Adolescent Risky Behavior, Journal of Adolescence, 33, 2010

Hurlock, E. B., Psikologi Perkembangan: Suatu Pendekatan Sepanjang Rentang Kebidupan, Jakarta: Erlangga, 2011

Kurniawansyah, R., Depresi Sering Dirundung Siswi SMA di Kampar Bunuh Diri, Media Indonesia [on-line], 2017. Diakses 20 September 2018 dari http://mediaindonesia.com/read/detail/115629-depresi-sering-dirundungsiswi-sma-di-kampar-bunuh-diri

Lewis, M., Jones, J, H., Barret, L, F., Handbook of Emotion Third Edition, New York: Published Guilford Press, 2008

Matsumoto, D., Takeuchi, S., Andayani, S., Kouznetsova, N., dan Krupp, D, The Contribution of Individualism vs. Collectivism to Crossnational Differences in Display Rules, Asian Journal ofS ocial Psychology, 1, 1998

Neff, K. D., dan McGehee, P., Self-compassion and Psychological Resilience Among Adolescent and Young Adults, Self and Identity, 9, 2010

Prahara, A, Seorang Pelajar di Inhil Akhiri Hidup dengan Gantung Diri, Spirit Riau [on-line], 2018. Diakses 20 September 2018 dari http://spiritriau.com/page/Indragirihulu/108812/view/Peristiwa/108819/S eorang-Pelajar-di-Inhil-Akhiri-Hidup-dengan-Gantung-Diri.html\#.W-1s_kzbIV 
Romer, N., Ravitch, K., Tom, K., Merrell, K. W., dan Wesley, K. L., Gender Differences In Positive Social-Emotional Functioning, Psychology In The Schools, Vol. 48, 2011

Santrock, J.W., Remaja Edisi kesebelas Jilid 1, Jakarta: Erlangga, 2007

Sani, A, Numpang Belajar di SMA lain Siswa di Pekanbaru Nyaris Tawuran. Merdeka [on-line], 2014. Diakses 20 September 2018 dari https://www.merdeka.com/peristiwa/numpang-belajar-di-sma-lain-siswa-dipekanbaru-nyaris-tawuran.html

Simon, R. W., dan Nath, L. E., Gender and Emotion in The United States: Do Men and Women Differ in Self-reports of Feelings and Expressive Behavior? American Journal of Sociology, 109, 2004

Sugiyono, Metode Penelitian Kuantitatif Kualitatif dan R\&D, Bandung: Alfabeta, 2016

Tanjung, B., Merampok Tiga Pelajar SMA di Pekanbaru Ditangkap. Sindonews [online], 2014. Diakses 20 September 2018 dari https://daerah.sindonews.com/read/928320/24/merampok-tiga-pelajarsma-di-pekanbaru-ditangkap-1416812993

Ubaidillah, Hubungan antara Regulasi Emosi dan Pengambilan Keputusan dalam Melakukan Transaksi di Pasar Valuta Asing pada Trader, Skripsi, Yogyakarta: Fakultas Ilmu Sosial dan Humaniora UIN Sunan Kalijaga, 2014 